\title{
The Influence of Mathematical Learning Material Based On Model-Eliciting Activities (MEAs) Approach To Improve Mathematical Creative Thinking Skill Of Students Of Grade X Of Senior High School Padang
}

\author{
Saddam Al Aziz \\ Department of Mathematics \\ Universitas Negeri Padang \\ Padang, Indonesia \\ bb.saddam@yahoo.com
}

\author{
Irwan \\ Department of Mathematics \\ Universitas Negeri Padang \\ Padang, Indonesia \\ irwan.math.165@gmail.com
}

\begin{abstract}
This paper discussed the effect of the learning tools to improve the creative thinking ability of high school students. This research used Plomp's model. Research subjects were 3 students in one to one stage, 9 students in small group stage, and 32 students in field test stage. The data were collected through interviews, questionnaires, analyzing student work, and final tests. The results showed that learning tools were categorized in a practical and effective way to increase the students'creative thinking ability.
\end{abstract}

Keywords: Creative thinking ability, Learning tools, Model Eliciting Activities (MEAs), Plomp's model

\section{INTRODUCTION}

One of the competencies in learning math that is important to be mastered by learners is the ability to think creatively. It is stated in [1] that the purpose of learning mathematics is that learners have the ability to think critically, logically, analytically, and creatively. The ability to think creatively is one of the high-level thinking skills essential to be developed in the 21 st century [2,3]. This ability is considered so important that it is referred to as one of the greatest assets of a nation [4]. This ability is desired by the world of work and becomes the determinant of a nation's superiority $[5,6]$.

Creative thinking is a process used when bringing in or bringing about a new idea. Creative thinking is a mental activity to increase the purity and originality of insight in generating [7]. This means that the ability to think creatively is an ability to produce or develop something new that is something unusual, which is different from the ideas generated by most people using the concepts obtained previously.

In fact, the creative thinking ability of learners has not developed to the fullest. The results of the creative thinking ability test performed by [8] also showed that less than 10 students who scored above the KKM and the grade point average less than 60. Then the results of the study [9] showed that 133 students from 3 schools which is the subject of research, generally shows that the creative thinking ability of learners is still low or less optimal. On a smaller scale, based on the results of observations and interviews, it was concluded that the use of LKPD that has not been optimal to be one of the causes of creative thinking ability of students is still low. This is not only happening in Indonesia but also in other countries. In most studies, US learners outperform learners in many other countries, especially learners in East Asian countries. He stated that the creativity of students and Americans is better than Chinese learners in solving open problems. This fact certainly applies also in Indonesia [10].

The cause of the low ability of creative thinking is a learning device that has not been able to facilitate, improve, and maximize the ability of creative thinking learners. Learning tools such as lesson plans and student worksheets (LKPD) are not optimal in their preparation, where lessons tend to be book-oriented and the types of issues are not comprehensive and not challenging [11]. In addition, the LKPD used tends to contain material summaries, sample questions, and exercise questions, no structured steps in packing material $[12,13]$. In addition, many teachers have not developed LKPD in the learning process [14].

Several studies suggest the importance of research on the creative thinking ability of learners. Suggestion from [6] that further research is needed about the creative thinking ability of learners because this ability is seen as a skill that must be possessed by learners. It added that further research is necessary because this ability is needed in solving various mathematical problems $[15,16]$. Then [5] suggested that the maximum follow-up research because the research is still many shortcomings.

One of the learning approaches considered to develop students' creative thinking skills is the model eliciting activities approach (MEAs), where the MEAs are a learning approach centered on the learner and the learner is facilitated to develop a mathematical model of the given problem. This approach emerged in the mid-1970s. MEAs stem from a problem-solving model in which learners are required to 
produce a structured and most effective and efficient model for solving a given problem $[17,18]$.

In the implementation, the MEA approach is implemented in small groups. The learning begins with problem-solving based on real-world situations, with small teams of 3 to 5 learners working to solve more than one or two problems. The most important problem-solving process of the MEAs approach is to present, test and review the model that will solve a problem. Meanwhile, according to [19], the MEAs approach is a learning approach for understanding, explaining, and communicating concepts embedded in problems with the model. Learning with the MEAs approach begins with a realistic problem to stimulate student interest. This interest will enable them to easily understand the problem because the problem is related to the daily life of the students. Once students understand the problem, it is hoped they can define and explore the steps to solve the problem. There are six principles in learning with the MEAs approach, namely: 1) Principle of meaning, 2) Principle of model construction, 3) Principle of selfevaluation, 4) Principle of model documentation, 5) Simple prototype principle, and 6) Model generalization principle.

So learning with the MEAs approach is a learnercentered learning where learners are facilitated to be more active in solving realistic mathematical problems and then creating mathematical models that are suitable for solving them [20,21].

The essence of MEAs is the creativity of learners in learning. Chamberlin [18] stated that creativity is the main thing that is put on MEAs and plays an important role in the success of learners in mathematics. With the presence of MEAs, the ability of learners to generate creative mathematical ideas in creating their own models to solve mathematical problems in response to well structured problems. So hopefully this makes the creative thinking ability of learners will develop.

In order for MEAs approach to run optimally, it is necessary a learning device that supports the implementation of phases in the approach of MEAs. Teaching process using the MEAs approach in the classroom will work well if teachers prepare a well-organized Learning Plan. The activities in the RPP are supported by the Student Worksheet [19]. Then [22] states that Government Regulation No.19 of 2005 article 20, indicates that teachers are expected to develop teaching materials as one learning resource that helps learners in achieving their competence. Then [11] states that what can be called LKPD is a teaching material that contains the tasks accompanied by instructions and steps in completing the task so as to enable learners to build knowledge and understanding independently and develop the expected ability.

This study aims to design lesson plans and student worksheets by using the MEAs approach which contains the steps and principles of the MEAs approach. In the learner's worksheet, it consists of problems that are not only routine but also non-routine issues and relate to the daily lives of learners so that they can easily understand what issues are being asked to them and what they should do to solve the problem the.

The MEAS approach is expected to improve the creative thinking ability of learners. This study describes the characteristics of instructional devices based on the approach of MEAs of class X students, which is practical and effective for improving the creative thinking ability of learners.

\section{RESEARCH METHODS}

This research is a developmental research. The development model used in this study was adapted from the Plomp Model. According to [23] that the Plomp development model consists of three stages: preliminary research, development or prototyping phase, and assessment phase. Meanwhile, the quality of the learning device developed results refer to the criteria proposed by Nieveen. According to [24] that the quality of development learning tools can be determined based on validity, practicality, and effectiveness. In this paper, we describe the practicality and effectiveness of the device.

The test subjects in this study are students of class $\mathrm{X}$ Padang Lesson Year 2017/2018. The trials in this study consisted of 3 stages, namely individual evaluation stage, small group evaluation stage, and field test phase. In the preliminary research phase is conducted needs analysis, curriculum analysis, concept analysis, and analysis of learners. The prototype development or design stage is designing and evaluating the prototype by referring to Tessmer's formative evaluation, which includes selfevaluation, expert review, one-to-one evaluation, small group and field test At the assessment stage.

Characteristics of the subjects of this study are learners who have different learning abilities (high, medium, low). There are several instruments used in this study, such as: a list of questions; checklist; sheet validation; observation sheet; questionnaire; and tests. Prior to use, all instruments are validated by experts.

Types of data from this study are qualitative data and quantitative data. Qualitative data obtained from the observation and interviews of teachers and learners. While the quantitative data obtained from the validation sheet, the results of questionnaire responses learners, and test the ability to think creatively mathematically learners. Qualitative data were analyzed based on qualitative paradigm and also quantitative data were analyzed based on quantitative paradigm. The final results of the study are categorized and summarized qualitatively.

\section{RESUlTS AND DISCUSSIONS}

In the requirement analysis phase, information gathering is done through classroom observation, interviewing the teacher, giving questionnaire and testing of the creative thinking ability of learners. To obtain information about the initial conditions of the students' creative abilities, they are given a test of creative thinking ability on the material they have learned. At the questionnaire stage, a questionnaire containing the statements about the mathematics learning and instructional material specifications are expected to the learners. All information obtained is analyzed as a basis for concluding the problems that arise as well as the causes, alternative solutions and product specifications expected by the learners and teachers.

Based on the results of needs analysis that has been done, it can be concluded that the required learning tools that can meet the needs of learners. In this case, the aforementioned 
device is a Lesson Plan and Student Worksheet. Learning devices are designed to address the problems experienced by learners during learning, especially in improving the ability to think creatively.

In the curriculum analysis phase, a review of the curriculum is used in schools. The review is done by analyzing the core competencies and basic competencies contained in the curriculum of 2013 grade X High School 2nd Semester of the academic year 2017/2018. Further develop or elaborate the basic competencies into indicators of achievement of competence and refers to the indicators of the ability to think creatively so that learning becomes directed and goals to be achieved clearly. The results of this analysis serve as a guide in the development of math-based learning tools MEAs.

At the concept analysis stage, identified the concepts to be discussed in the lesson. These concepts are arranged systematically by linking a concept with another relevant concept to form a new concept. This analysis aims to determine the content and subject matter that can be presented on the learning device. The results of the analysis are used to prepare aspects related to the design and development of learning tools of mathematics.

In the learner's analysis phase, observation of the learning process in the classroom and giving the questionnaire to learners to know their characteristics. These characteristics include the academic ability gained on the basis of information from the teacher, the learner's interest in the colored teaching materials, the learner's tendencies in learning and the difficulties faced by the learner during the learning process.

The learning tools in this research are Lesson Plan and Student Worksheet based on MEAs approach. The Lesson Plan based approach of MEAs is an implementation plan or learning scenario that is structured to support the implementation of learning with the MEAs approach. The learning activities contained in the lesson plan are tailored to the MEAs approach learning steps, which in each activity are undertaken under the guidance of the teacher. While Student Worksheet based on MEAs is a learner's work sheet that contains a number of explanations, activities, questions, commands and math problems, which facilitate learners to be active in solving realistic mathematical problems then create mathematical models that are suitable to solve them. The arrangement of activities, questions or orders presented in the Student Worksheet is adjusted to the order of MEAs steps.

There are 4 sections in the MEAs approach. According to [18] that the first two sections aim to build students' understanding of the contexts and parameters of the reading section and the readiness readiness section. In these first two sections, there is little emphasis on creativity development. Instead, the emphasis is on helping learners understand the context of the problem. Meanwhile, the last two sections aim to find problem solving. In the last two sections there is more emphasis on creative development of learners. In line with that, according to [19], there are five learning steps with the approach of MEAs. The first step, learning begins with the teacher asks students to read and understand the story or article given on the sheet of problems contained in the Student Worksheet. The second step is to ensure the readiness of learners to the questions presented in the articles contained in the Student Worksheet. The third step is, the teacher asks the learners to read the given problem and make sure each group understands the problem given in the problem sheet. The fourth step of learning the MEAs is that the learners try to solve the problem to produce the model as the ultimate solution of the problem. In this step, learners discuss and try to build models to solve problems. The fifth step is that the problem must be solved by the learners in the group.

\section{CONCLUSION}

Based on the analysis of research results, it is concluded that the learning tools based on the MEAs approach generated in this study are categorized as practical and effective. This means that this learning tool is easy to use by teachers and learners. The aspect of pratikalitas in this case is in terms of ease of use, attractiveness, language used, and time. The learning tools based on the MEAs approach generated in this study are also categorized as effective because they are able to improve the creative thinking ability of learners. This is because learning using the MEAs approach allows learners to develop a model that represents or represents a problem first, then completes the model until a solution is found from the given problem. It is this habit that improves the creative thinking ability of learners.

This developed learning tool can be used as an additional learning resource for teachers and learners. Then, through this learning tool is expected to help teachers and learners in achieving learning objectives, especially with the aim of improving the ability to think creatively learners. It is hoped that this learning tool can also be used in other schools.

\section{REFERENCES}

[1] Kemendikbud, "Modul Pelatihan Implementasi Kurikulum 2013 untuk Matematika Tingkat SMP/MTs". Jakarta: Departemen Pendidikan Nasional. (Online), pp.267. (https://s3.amazonaws.com/academia.edu, accessed 2 Agustus 2017), 2013.

[2] Yusnaeni, et al, "Creative Thinking of Low Academic Student Undergoing Search Solve Create and Share Learning Integrated with Metacognitive Strategy. International Journal of Instruction". (Online), vol. 10, pp.246, (http://search.ebscohost.com, accessed 29 Oktober 2017), 2017.

[3] Wessels. Helena, "Levels Of Mathematical Creativity In ModelEliciting Activities. Journal of Mathematical Modelling and Application”, (Online), vol. 1, pp.1. (http://gorila.furb.br, accessed 2 Agustus 2017), 2014.

[4] Coxbill Emmy, Scott A. Chamberlin, dan Jennifer Weatherford, "Using Model-Eliciting Activities As a Tool to Identify and Develop Mathematically Creative Students. Journal for The Education of The Gifted", (Online), vol. 36, pp. 183, (http://search.ebscohost.com, accessed 25 November 2017), 2013.

[5] Mursidik, Elly's Mersina, "Kemampuan Berpikir Kreatif Dalam Memecahkan Masalah Matematika Open-Ended Ditinjau Dari Tingkat Kemampuan Matematika Pada Peserta didik Sekolah Dasar", (Online), vol. 4 pp. 23, (http://ojs.umsida.ac.id/index.php, accessed 25 November 2017), 2015.

[6] Kurniawati. Nia, "Analisis Kemampuan Berpikir Kreatif Matematis Peserta didik Kelas V Sekolah Dasar Dalam Pembelajaran Matematika: Studi Kualitatif Analisis Kemampuan Berpikir Kreatif Matematis Peserta didik Kelas V Sekolah Dasar Dalam Pembelajaran Matematika", (Tesis), pp.110, (http://repository.upi.edu, accessed 20 September 2017), 2012.

[7] Istianah. Euis, "Meningkatkan Kemampuan Berpikir Kritis Dan Kreatif Matematik Dengan Pendekatan Model Eliciting Activities (MEAs) Pada Peserta didik SMA", Jurnal Ilmiah Program Studi 
Matematika STKIP Siliwangi Bandung. (Online), vol.2, pp.46. (http://e-journal.stkipsiliwangi.ac.id, accessed 2 Agustus 2017), 2013

[8] Ayuningtyas.Winda, "Pengaruh Pendekatan Model Eliciting Activities (MEAs) Terhadap Kemampuan Berpikir Kritis Dan Kreatif Matematis Peserta didik", (Online), pp. 6 . (http://repository.uinjkt.ac.id, accessed 2 Agustus 2017), 2015

[9] Meika. Ika, "Kemampuan Berpikir Kreatif Dan Pemecahan Masalah Matematis Peserta didik SMA", JPPM. (Online), vol. 10, pp. 10 (http://eprints.ums.ac.id, accessed 2 November 2017), 2017.

[10] Harpen. Xianwei, "Creativity And Mathematical Problem Posing: An Analysis Of High School Students' Mathematical Problem Posing In China And The USA", Educ Stud Mat. (Online), vol. 82, pp.203. (http://search.ebscohost.com, accessed 2 November 2017), 2012

[11] Loviana. Selvi, "Pengembangan LKPD Dengan Menggunakan Model Problem Based Learning Untuk Memfasilitasi Kemampuan Komunikasi Dan Disposisi Komunikasi (Studi pada Peserta didik Kelas VIII Semester Ganjil SMP Negeri 9 Metro Tahun Pelajaran 2015/2016)", (Tesis), pp.2-3. (http://digilib.unila.ac.id, accessed 2 Agustus 2017), 2016.

[12] Iqbal. Muhammad, "Pengembangan Lembar Kerja Peserta Didik (LKPD) Dengan Pendekatan Kontekstual Ditinjau Dari Pemahaman Konsep Dan Disposisi Matematis", (Tesis), pp.11. (http://digilib.unila.ac.id, accessed 25 November 2017), 2017.

[13] Barlenti. Ilmas, "Pengembangan LKPD Berbasis Project Based Learning Untuk Meningkatkan Kemampuan Pemahaman Konsep. Jurnal Pendidikan Sains Indonesia", (Online), vol. 5, pp.82. (http://www.jurnal.unsyiah.ac.id, diakses 27 November 2017), 2017.

[14] Pansa. Hani Ervina, " Pengembangan LKPD Dengan Model Problem Based Learning (PBL) Untuk Meningkatkan Kemampuan Komunikasi Matematis Siswa. Seminar Nasional Matematika dan Pendidikan Matematika 2017”, (Online), Vol. 1, pp.231 (http://download.portalgaruda.org, accessed 25 November 2017), 2017.

[15] Rahmazatullaili, "Kemampuan Berpikir Kreatif Dan Pemecahan Masalah Siswa Melalui Penerapan Model Project Based Learning. Jurnal Tadris Matematika", (Online), Vol. 10, (http://jurnalbeta.ac.id, accessed 1 Januari 2018), 2017.

[16] Solehuzain, "Kemampuan Berpikir Kreatif dan Rasa Ingin Tahu pada Model Problem-Based Learning dengan Masalah Open Ended. UNNES Journal of Mathematics Education Research", (Online), Vol.
6, No.1, (http://journal.unnes.ac.id/sju/index.php/ujmer, accessed 2 Januari 2018), 2017.

[17] Khrine. Myith Swe, "Model and Modeling Cognitive Tools For Scientific Enquiry", Australia: Springer Science. (Online), (http://en.bookfi.net/book/1242638, accessed 2 Agustus 2017), 2011.

[18] Chamberlin. Scott A, and Sidney M. Moon, "Model-Eliciting Activities as a Tool to Develop and Identify Creatively Gifted Mathematicians, The Journal of Secondary Gifted Education. (Online), Vol. 17, (http://journals.sagepub.com, 2 Agustus 2017), 2005

[19] Irwan, "The Development Of Mathematical Learning Material Based On Model-Eliciting Activities (MEAs) Approach To Improve Mathematical Problemsolving Skill Of Students Of Grade X of Senior High School Padang", Journal of Physics: Conference Series. International Conference on Mathematics and Natural Sciences (IConMNS 2017). (Online), pp. 2. (https://www.atlantis-press.com, 23 Juni 2018), 2018

[20] Hamilton. Eric, et al, "Model-Eliciting Activities (MEAs) as a Bridge Between Engineering Education Research and Mathmatics Education Research, Advance in Engineering Education", (Online), (http://advances.asee.org, diakses 2 Agustus 2017), 2008.

[21] Hidayat. Wahyu, "Penerapan Pembelajaran MEAs Terhadap Peningkatan Daya Matematik Siswa SMA. Prosiding Seminar Nasional Pendidikan Matematika", (Online), Vol. 1, (http://publikasi.stkipsiliwangi.ac.id, accessed 2 Agustus 2017), 2014.

[22] Wafiqoh. Risnina, "LKPD Berbasis Model Eliciting Activities Untuk Mengetahui Kemampuan Pemecahan Masalah Matematika Di Kelas VIII", Jurnal Elemen. (Online), vol. 2, (http://ejournal.hamzanwadi.ac.id, accessed 2 Agustus 2017), 2016.

[23] Plomp, Tjeerd, and Nienke Nieveen, "Educational Design Research", (http://downloads.slo.nl/Documenten/educational-design-researchpart-a.pdf, accessed 2 Agustus 2017), 2013.

[24] Nieveen, Nienke, Jan van den Akker, Robert Maribe Branch, and Kent Gustafson, "Design Approaches and Tools in Education and Training", pp.127. (https://www.researchgate.net, accessed 2 Agustus 2017), 1999.

[25] Irwan, "Development of Mathematical Learning Materials Based on Model Eliciting Activities Approach to Improve the Mathematical Reasoning Ability Student Class X SMA Padang", Advances in Social Science, Education and Humanities Research (ASSEHR). (Online), vol. 160, pp.286-289. (http://iopscience.iop.org, 23 Juni 2018), 2017. 